This document is confidential and is proprietary to the American Chemical Society and its authors. Do not copy or disclose without written permission. If you have received this item in error, notify the sender and delete all copies.

\title{
Investigating Lysine Adsorption on Fumed Silica Nanoparticles
}

\begin{tabular}{|r|l|}
\hline Journal: & The Journal of Physical Chemistry \\
\hline Manuscript ID: & jp-2014-08627h \\
\hline Manuscript Type: & Article \\
\hline Date Submitted by the Author: & $26-$ Aug-2014 \\
\hline & $\begin{array}{l}\text { Guo, Chengchen; Arizona State University, Department of Chemistry and } \\
\text { Biochemistry } \\
\text { Holland, Gregory } \\
\text { and Biochemistry }\end{array}$ \\
\hline
\end{tabular}

\section{SCHOLARONE" \\ Manuscripts}




\title{
Investigating Lysine Adsorption on Fumed Silica Nanoparticles
}

\author{
Chengchen $\mathrm{Guo}^{\dagger}$, Jeffery L. Yarger ${ }^{\dagger *}$, Gregory P. Holland ${ }^{\dagger *}$ \\ ${ }^{\dagger}$ Department of Chemistry and Biochemistry, Magnetic Resonance Research Center, Arizona State University, Tempe, \\ Arizona 85287-1604, United States \\ *Department of Chemistry and Biochemistry, San Diego State University, San Diego, California 92182-1030, United States
}




\begin{abstract}
The adsorption of amino acids on silica surfaces has attracted considerable interest since it has a broad range of applications in various fields such as drug delivery, solid-phase peptide synthesis and biocompatible materials synthesis. In this work, we systematically study lysine adsorption on fumed silica nanoparticles with thermal analysis and solid-state NMR. Thermal-gravimetric analysis (TGA) results show that the adsorption behavior of lysine in low concentration aqueous solutions is well described by the Langmuir isotherm. With ultrafast magic-angle-spinning (MAS) ${ }^{1} \mathrm{H}$ NMR and multinuclear and multi-dimensional ${ }^{13} \mathrm{C}$ and ${ }^{15} \mathrm{~N}$ solid-state NMR, we successfully determine the protonation state of bulk lysine and find that lysine is adsorbed on silica nanoparticles surfaces through the sidechain amine groups. Density functional theory (DFT) calculations carried out on lysine and lysinesilanol complex structures further confirm that the side-chain amine groups interact with the silica surface hydroxyl groups via strong hydrogen bonding. Furthermore, we find that lysine preferentially has monolayer coverage on silica surfaces in high salt concentration solutions because of the ionic complexes formed with surface bound lysine molecules.
\end{abstract}

\title{
KEYWORDS
}

Fumed silica nanoparticles, Lysine, Adsorption behavior, Solid-state NMR, Ultrafast MAS ${ }^{1} \mathrm{H}$ NMR, Density Functional Theory Calculation. 


\section{INTRODUCTION}

The nature of interactions between biomolecules and the surfaces of inorganic materials has attracted considerable attention since it is of great significance in many promising fields, such as prebiotic chemistry ${ }^{1-3}$, bio-nanotechnology ${ }^{4-9}$ and drug delivery ${ }^{10-14}$. For instance, some minerals have been shown to catalyze peptide synthesis, providing a new explanation on the origin of life. ${ }^{2,15}$ In addition, some biomolecules with pharmaceutical properties can be adsorbed at specific inorganic material interfaces and then released in vivo in a well-controlled way. ${ }^{11,14}$ Adsorption of amino acids and peptides on silica surfaces is one specific class of such bioorganic-inorganic interface systems. Silica was extensively studied and utilized for various applications such as catalysis, solar cells and even cancer therapy. ${ }^{4,11,16}$ Fumed silica (Cab-O-Sil) is one class of synthetic silica materials with a high surface area. ${ }^{17}$ It is produced at high temperature by hydrolyzing silicon tetrachloride vapor in a flame followed by rapid quenching to room temperature. Due to this, it acquires some unique characteristics such as amorphous structure, nanoscale size and an extensively high surface area. The studies of surface chemistry at fumed silica interfaces have been carried out for decades because of the considerable utility of high surface area amorphous silicates. ${ }^{17-25}$

Lysine (Lys) has been used in a large number of studies due to its unique structure, where there is one single side chain amine group. It is this side chain amine group that makes lysine the simplest basic amino acid compared with the other two basic amino acids, arginine and histidine. Due to this, lysine has been used in synthesizing a range of nanomaterials. ${ }^{26-28}$ Recently, Yokoi et al discovered that lysine is a good ligand in synthesizing ultra-small silica nanoparticles $(<10 \mathrm{~nm})$ that show great potential in future nanotechnology applications. ${ }^{27}$ Figure 1 shows the summary of different L-lysine forms and the charged state of a silica surface at variable $\mathrm{pH}$ values. ${ }^{29-31}$ The structure of bulk lysine has not been clearly defined but the structure of lysine mono-hydrochloride dihydrate was determined by X-ray diffraction (XRD) and neutron scattering techniques. ${ }^{32,33}$ 
Considerable work has been done to understand the interaction between amino acids and silica surfaces where the focus was on alanine and glycine adsorption. ${ }^{34-40}$ Considerably less work has been performed to study lysine adsorption on silica surfaces. ${ }^{31,41,42}$ The main techniques that have been used to study the adsorption behavior of lysine on surfaces of inorganic materials are IR spectroscopy and thermal analysis. By using IR spectroscopy, it is easy to determine the protonation state of lysine on surfaces at variable $\mathrm{pH}$ values. ${ }^{31,41}$ Thermal analysis, including thermal-gravimetric analysis (TGA) and differential scanning calorimetry (DSC), has also been applied to study the thermal transformation of lysine molecules on surfaces. ${ }^{38}$ To date, solid-state NMR techniques have not been used to study lysine adsorption and thermal transformation of lysine molecules at silica interfaces. Compared with thermal analysis, solid-state NMR is able to provide molecular and atomic level details. ${ }^{43}$ Many solid-state NMR methods and techniques have been developed and applied to study the interaction between amino acids and silica surfaces. ${ }^{34-37,44-46}$ Schmidt et al. used rotational-echo double-resonance (REDOR) NMR to investigate the adsorbed state and the local dynamics of alanine molecules on silica surface and they proposed that alanine is more mobile when hydrated. ${ }^{44}$ Also, Vega et al. used ${ }^{2} \mathrm{H}$ NMR to study the dynamics of water and alanine molecules adsorbed on silica surfaces. ${ }^{36}$

In the present work, we applied solid-state NMR techniques including ultrafast magic-anglespinning ${ }^{47}$ (MAS) ${ }^{1} \mathrm{H}$ NMR and multi-nuclear and multi-dimensional ${ }^{13} \mathrm{C}$ and ${ }^{15} \mathrm{~N} N \mathrm{NR}$ to determine the structure of bulk lysine and investigate lysine adsorbed on fumed silica nanoparticles. Furthermore, in order to elucidate the interaction between lysine and silanol groups on silica surfaces, we performed density functional theory ${ }^{48,49}$ (DFT) calculations for ${ }^{1} \mathrm{H},{ }^{13} \mathrm{C},{ }^{15} \mathrm{~N}$ chemical shifts of lysine-silanol complex species and geometries. The combination of NMR experiments with DFT calculations allows us to propose structural models for lysine interacting at silica nanoparticle interfaces. 


\section{EXPERIMENTAL SECTION}

Materials. Fumed silica nanoparticles $(\sim 7 \mathrm{~nm})$ with BET (Brunauer, Emmett and Teller) surface area of $395 \pm 25 \mathrm{~m}^{2} / \mathrm{g}$ and pure L-lysine (99\% purity) were purchased from Sigma-Aldrich. U- $\left[{ }^{15} \mathrm{~N},{ }^{13} \mathrm{C}\right]-$ L-lysine $\cdot 2 \mathrm{HCl}$ was purchased from Cambridge. Isotopes. Inc. All materials were used as received and the stable isotope enrichment levels of labeled compounds are $98 \%$. U- $\left[{ }^{15} \mathrm{~N},{ }^{13} \mathrm{C}\right]-\mathrm{L}-1 \mathrm{ysine} \cdot 2 \mathrm{NaCl}$ was prepared by crystallizing in DI water after adjusting to $\mathrm{pH} \sim 10$ with $1.0 \mathrm{M} \mathrm{NaOH}$.

Sample Preparation. Fumed silica nanoparticles used in the study were initially heated up to $500{ }^{\circ} \mathrm{C}$ for 24 hours to remove free water and impurities on the surface. In a typical adsorption procedure, 150 $\mathrm{mg}$ of fumed silica nanoparticles was immersed in a $10.0 \mathrm{~mL}$ aqueous solution of L-lysine with varying concentrations and the solution was stirred at room temperature for 3 hours to ensure the adsorption reached equilibrium. The solid was then separated by centrifugation and carefully dried under vacuum at $30{ }^{\circ} \mathrm{C}$ for over 15 hours. The samples prepared from solutions of various concentrations were noted as $\mathrm{Lys} / \mathrm{SiO}_{2}-\mathrm{xM}$, where $\mathrm{x}$ refers to the lysine concentration in the adsorption solution (in $\mathrm{mol} \cdot \mathrm{L}^{-1}$ ). Since all experiments were carried out in pure DI water, the $\mathrm{pH}$ values of all the solutions are around 10.0 (10.0 \pm 0.3$)$, corresponding to the isoelectric $\mathrm{pH}$ value of lysine in pure water.

To prepare ${ }^{13} \mathrm{C},{ }^{15} \mathrm{~N}$-L-lysine adsorbed fumed silica samples, $60.0 \mathrm{mg}$ fumed silica nanoparticles and $9.0 \mathrm{mg}{ }^{13} \mathrm{C},{ }^{15} \mathrm{~N}$-L-lysine $2 \mathrm{HCl}(0.01 \mathrm{M})$ were mixed in DI water and the solution $\mathrm{pH}$ was adjusted to 10.0 with $1.0 \mathrm{M} \mathrm{NaOH}$. The volume of the final solution is $4.0 \mathrm{~mL}$ and the suspension was then stirred for 3 hours to reach equilibrium. The mixture was then centrifuged and the remaining powder was allowed to vacuum dry at $30^{\circ} \mathrm{C}$ for over 15 hours.

Thermal-gravimetric Analysis (TGA). TGA experiments were performed on $\mathrm{Lys} / \mathrm{SiO}_{2}-\mathrm{xM}$ samples with a TA2910 (TA Instrument Inc.) under $\mathrm{N}_{2}$ flow $(60 \mathrm{~mL} / \mathrm{min}$ for furnace and $40 \mathrm{~mL} / \mathrm{min}$ for balance). The heating rate was $5{ }^{\circ} \mathrm{C} / \mathrm{min}$ and for each experiment, 7-10 $\mathrm{mg}$ of sample was used. Before each experiment, the sample was kept under a $\mathrm{N}_{2}$ flow for 10 min to remove most of the physisorbed water and obtain a stable baseline. 
Solid-state NMR Spectroscopy. ${ }^{1} \mathrm{H} \rightarrow{ }^{13} \mathrm{C}$ and ${ }^{1} \mathrm{H} \rightarrow{ }^{15} \mathrm{~N}$ cross-polarization magic-anglespinning ${ }^{50,51}$ (CP-MAS) NMR experiments, two-dimensional (2D) ${ }^{13} \mathrm{C}-{ }^{13} \mathrm{C}$ through-space correlation NMR experiments with dipolar-assisted rotational resonance ${ }^{52,53}$ (DARR), $2 \mathrm{D}{ }^{13} \mathrm{C}-{ }^{13} \mathrm{C}$ through-bond double-quantum (DQ)/single-quantum (SQ) refocused incredible natural abundance double quantum transfer NMR experiments ${ }^{54,55}$ (INADEQUATE) and 2D ${ }^{15} \mathrm{~N}-{ }^{13} \mathrm{C}$ heteronuclear correlation (HETCOR) NMR experiments were performed on Varian VNMRS $400 \mathrm{MHz}$ spectrometer. For the U- $\left[{ }^{15} \mathrm{~N}\right.$, $\left.{ }^{13} \mathrm{C}\right]-\mathrm{L}-$ lysine $\cdot 2 \mathrm{HCl}$ and natural abundance $\mathrm{Lys} / \mathrm{SiO}_{2}$ samples, $2 \mathrm{D}{ }^{13} \mathrm{C}-{ }^{13} \mathrm{C}$ correlation experiments and $\mathrm{CP}-\mathrm{MAS}$ NMR experiments were collected with a $4.0 \mathrm{~mm}$ triple resonance probe operating in triple resonance $\left({ }^{1} \mathrm{H} /{ }^{13} \mathrm{C} /{ }^{15} \mathrm{~N}\right)$ mode at a MAS speed of $10 \mathrm{kHz}$. The $\mathrm{CP}$ condition for ${ }^{1} \mathrm{H} \rightarrow{ }^{13} \mathrm{C}$ CP-MAS NMR experiments consisted of a $4.0 \mu \mathrm{s}{ }^{1} \mathrm{H} \pi / 2$ pulse, followed by a $2.0 \mathrm{~ms}$ ramped $(8 \%){ }^{1} \mathrm{H}$ spin-lock pulse of $62.5 \mathrm{kHz}$ radio frequency (rf) field strength. The experiments were performed with a $50 \mathrm{kHz}$ sweep width, a recycle delay of $3.0 \mathrm{~s}$ and two-pulse phase-modulated ${ }^{56}$ (TPPM) ${ }^{1} \mathrm{H}$ decoupling level of $65 \mathrm{kHz}$. The CP condition for ${ }^{1} \mathrm{H} \rightarrow{ }^{15} \mathrm{~N}$ CP-MAS NMR experiments consisted of a $3.25 \mu \mathrm{s}{ }^{1} \mathrm{H} \pi / 2$ pulse, followed by a $1.0 \mathrm{~ms}$ ramped $(10 \%){ }^{1} \mathrm{H}$ spin-lock pulse of $75 \mathrm{kHz}$ rf field strength. The experiments were performed with a $50 \mathrm{kHz}$ sweep width, a recycle delay of $3.0 \mathrm{~s}$ and ${ }^{1} \mathrm{H}$ decoupling level of $80 \mathrm{kHz}$. For the ${ }^{13} \mathrm{C},{ }^{15} \mathrm{~N}$-labeled Lys $/ \mathrm{SiO}_{2}$ samples, CP-MAS NMR experiments and $2 \mathrm{D}{ }^{15} \mathrm{~N}-{ }^{13} \mathrm{C}$ HETCOR NMR experiments were collected with a $3.2 \mathrm{~mm}$ triple resonance probe operating in triple resonance $\left({ }^{1} \mathrm{H} /{ }^{13} \mathrm{C} /{ }^{15} \mathrm{~N}\right)$ mode at a MAS speed of $10 \mathrm{kHz}$. For ${ }^{1} \mathrm{H} \rightarrow{ }^{13} \mathrm{C} \mathrm{CP}-\mathrm{MAS}$ NMR experiments, the CP condition consisted of a $2.5 \mu \mathrm{s}{ }^{1} \mathrm{H} \pi / 2$ pulse, followed by a $1.0 \mathrm{~ms}$ ramped $(8 \%){ }^{1} \mathrm{H}$ spin-lock pulse of $100 \mathrm{kHz}$ rf field strength. The experiments were performed with a $50 \mathrm{kHz}$ sweep width, a recycle delay of $3.0 \mathrm{~s}$ and ${ }^{1} \mathrm{H}$ decoupling level of $90 \mathrm{kHz}$. For ${ }^{1} \mathrm{H} \rightarrow{ }^{15} \mathrm{~N}$ CP-MAS NMR experiments, the CP condition consisted of $2.5 \mu \mathrm{s}{ }^{1} \mathrm{H} \pi / 2$ pulse, followed by a $1.0 \mathrm{~ms}$ ramped $(12 \%){ }^{1} \mathrm{H}$ spin-lock pulse of $55 \mathrm{kHz} \mathrm{rf}$ field strength. The experiments were performed with a $25 \mathrm{kHz}$ sweep width, a recycle delay of $5.0 \mathrm{~s}$ and ${ }^{1} \mathrm{H}$ decoupling level of $90 \mathrm{kHz} .2 \mathrm{D}{ }^{13} \mathrm{C}-{ }^{13} \mathrm{C}$ through-space correlation NMR experiments, $2 \mathrm{D}{ }^{13} \mathrm{C}-{ }^{13} \mathrm{C}$ INADEQUATE and $2 \mathrm{D}{ }^{15} \mathrm{~N}-{ }^{13} \mathrm{C}$ HETCOR NMR experiments were used for assigning resonances (see supporting information for data and experimental details). 
${ }^{1} \mathrm{H}$ MAS NMR experiments and 2D ${ }^{1} \mathrm{H}-{ }^{13} \mathrm{C}$ HETCOR NMR experiments were carried out on Varian VNMRS $800 \mathrm{MHz}$ with a $1.6 \mathrm{~mm}$ triple resonance probe operating in double resonance $\left({ }^{1} \mathrm{H} /{ }^{13} \mathrm{C}\right) \mathrm{mode}$. ${ }^{1} \mathrm{H}$ MAS NMR experiments were collected with $2.0 \mu \mathrm{s}{ }^{1} \mathrm{H} \pi / 2$ pulse, $25 \mathrm{kHz}$ sweep width at $30 \mathrm{kHz}$ MAS. 2D ${ }^{1} \mathrm{H}^{13} \mathrm{C}$ HETCOR NMR experiments were done at spinning speed of $35 \mathrm{kHz}$. The ${ }^{1} \mathrm{H} \rightarrow{ }^{13} \mathrm{C} \mathrm{CP}$ condition consisted of a $2.6 \mu \mathrm{s}{ }^{1} \mathrm{H} \pi / 2$ pulse, followed by a ramped $(10 \%){ }^{1} \mathrm{H}$ spin-lock pulse of 100 $\mathrm{kHz}$ rf field strength of variable contact time $(0.25 \mathrm{~ms}, 2.0 \mathrm{~ms})$. The sweep widths of direct dimension and indirect dimension are $50 \mathrm{kHz}$ and $25 \mathrm{kHz}$ respectively with 32 complex $t_{1}$ points. The recycle delay was $3.0 \mathrm{~s}$ and TPPM ${ }^{1} \mathrm{H}$ decoupling with a rf field strength of $110 \mathrm{kHz}$ was used during acquisition.

Ultrafast ${ }^{1} \mathrm{H}$ MAS NMR experiments and ${ }^{1} \mathrm{H}^{-1} \mathrm{H}$ back-to-back ${ }^{57-59}$ (BABA) dipolar DQ/SQ correlation NMR experiments were carried out on a Bruker AVIII $850 \mathrm{MHz}$ spectrometer equipped with a $1.3 \mathrm{~mm}$ double resonance probe $\left({ }^{1} \mathrm{H} /{ }^{13} \mathrm{C}\right)$ at a MAS speed of $67 \mathrm{kHz}$. The experiments were done with one rotor period BABA for excitation and reconversion, a $1.5 \mu \mathrm{s}{ }^{1} \mathrm{H} \pi / 2$ pulse, relaxation delay of $5.0 \mathrm{~s}$ and 128 complex $t_{1}$ points. In all experiments, the chemical shifts of ${ }^{1} \mathrm{H},{ }^{13} \mathrm{C}$ and ${ }^{15} \mathrm{~N}$ were indirectly referenced to adamantane ${ }^{1} \mathrm{H}(1.63 \mathrm{ppm})$, adamantane ${ }^{13} \mathrm{C}(38.6 \mathrm{ppm})$ and glycine ${ }^{15} \mathrm{~N}(31.6 \mathrm{ppm})$, respectively.

DFT Calculation. Both geometry optimization and NMR chemical shifts calculation were performed with B3LYP DFT method using 6-31G+(d, p) basis sets in Gaussian09. ${ }^{62}$ It is well demonstrated that the B3LYP/6-31G $+\left(\mathrm{d}\right.$, p) level can provide reliable NMR chemical shift results. ${ }^{63-65}$ To reduce the computational cost, we used a silanol $\left(\mathrm{HOSiH}_{3}\right)$ molecule instead of using a complete silica surface model. In the calculations, bulk lysine and lysine/silanol complex species (Figure 2a, 2b.) were geometrical optimized first and then the optimized structures were used in NMR chemical shift calculations. NMR chemical shifts calculations were performed using the Gauge-Including Atomic Orbital ${ }^{66,67}$ (GIAO) method and ${ }^{1} \mathrm{H},{ }^{13} \mathrm{C}$ and ${ }^{15} \mathrm{~N}$ chemical shift values were analyzed. In ${ }^{13} \mathrm{C}$ and ${ }^{15} \mathrm{~N}$ data analysis, we applied two extrapolated curves for ${ }^{13} \mathrm{C}$ and ${ }^{15} \mathrm{~N}$ respectively to transform all calculated chemical shielding values to chemical shift values. This method is demonstrated to be more 
accurate than simply using a standard reference. ${ }^{63,64}$ For ${ }^{1} \mathrm{H}$, the calculated chemical shifts were referenced to ${ }^{1} \mathrm{H}$ chemical shift of tetramethylsilane (TMS) calculated with the same basis set.

\section{RESULTS AND DISCUSSION}

Protonation State of L-Lysine in the Solid State. The ${ }^{1}$ H MAS NMR spectra of natural abundance bulk lysine at different MAS speeds are shown in Figure $3 \mathrm{~A}$ and the $2 \mathrm{D}{ }^{1} \mathrm{H}-{ }^{1} \mathrm{H}$ dipolar DQ/SQ NMR spectrum collected with the BABA pulse sequence is shown in Figure 3B. With increasing spinning speed, the resolution of the ${ }^{1} \mathrm{H}$ MAS NMR spectrum for bulk lysine is improved dramatically with wellresolved resonances observed for the spectrum collected with a $67 \mathrm{kHz}$ MAS speed. According to 2D ${ }^{1} \mathrm{H}-{ }^{13} \mathrm{C}$ HETCOR NMR spectrum (Figure S1), the resonances at $3.6 \mathrm{ppm}$ and $2.2 \mathrm{ppm}$ were assigned to $\alpha-\mathrm{CH}$ and $\varepsilon-\mathrm{CH}_{2}$ respectively and that the broad component at $1.5 \mathrm{ppm}$ is a combination of $\beta-\mathrm{CH}_{2}, \gamma-$ $\mathrm{CH}_{2}, \delta-\mathrm{CH}_{2}$. It is difficult to determine the protonation states of the amine groups in bulk lysine from the ${ }^{1} \mathrm{H}$ MAS and $2 \mathrm{D}{ }^{1} \mathrm{H}-{ }^{13} \mathrm{C}$ HETCOR NMR experiments. ${ }^{1} \mathrm{H}-{ }^{1} \mathrm{H}$ DQ/SQ NMR experiment with a MAS speed of $67 \mathrm{kHz}$ was applied to better assign the ${ }^{1} \mathrm{H}$ spectrum. In the ${ }^{1} \mathrm{H}-{ }^{1} \mathrm{H}$ DQ/SQ NMR spectrum, the resonance at $3.6 \mathrm{ppm}$ was assigned to $\alpha-\mathrm{CH}$ since it has no on diagonal resonance and this result is consistent with the $2 \mathrm{D}{ }^{1} \mathrm{H}-{ }^{13} \mathrm{C}$ HETCOR NMR result. The resonance at $8.4 \mathrm{ppm}$ was assigned to $\alpha-\mathrm{NH}_{3}{ }^{+}$ because only strong DQ correlation to $\alpha-\mathrm{CH}$ was observed with no obvious DQ correlation to $\varepsilon-\mathrm{CH}_{2}$ (dashed circle). The result indicates that $\varepsilon-\mathrm{NH}_{2}$ is not protonated in bulk lysine and it has a relatively small resonance that is probably convoluted by the broad component in the $0-2 \mathrm{ppm}$ region of the spectrum. DFT calculation further suggests that the $\varepsilon-\mathrm{NH}_{2}$ resonance probably appears around $0.7 \mathrm{ppm}$. The protonation state of lysine in its bulk form is as proposed in Fig 3A and takes on the zwitterion form observed for most amino acids such as alanine and glycine.

Adsorption Behavior of Lysine on Fumed Silica Nanoparticles. TGA is an accurate technique to measure the amount of adsorbed lysine on fumed silica nanoparticles. Since all adsorbed amino acids will completely decompose when heating to $600^{\circ} \mathrm{C}$, we can quantify the amount of lysine on the surface from TGA curves. Figure 4A shows the TGA curves for lysine/silica samples prepared from solutions 
with different initial lysine concentrations. Clearly, with increasing initial concentration, the surface coverage increases. The quantitative results of TGA are presented in Table 1. As expected, it shows that the adsorbed amount of lysine increases when increasing the initial lysine concentration in solution. The adsorption behavior of lysine molecules is described in Figure 4B. We applied Langmuir isotherm to fit the data, showing that at low concentration, the adsorption behavior of lysine fits well to a Langmuir isotherm but the fitting deviates at high concentration (Figure 4B). This is mostly because at high concentration, the adsorption behavior of lysine not only depends on the state of the surface, but also on the interaction between lysine molecules. Based on the Langmuir isotherm fitting result for the first 5 points, ideally, the maximum amount of adsorbed lysine is $2.3 \pm 0.2 \mathrm{molecule} / \mathrm{nm}^{2}$ and the equilibrium constant is $32.2 \pm 8.6 \mathrm{M}^{-1}$.

\section{Adsorption State of Lysine on Fumed Silica Nanoparticles. ${ }^{1} \mathrm{H} \rightarrow{ }^{13} \mathrm{C}$ and ${ }^{1} \mathrm{H} \rightarrow{ }^{15} \mathrm{~N} \mathrm{CP}-\mathrm{MAS}$ NMR} experiments were applied in this work to investigate the adsorption state of lysine at interfaces of nanoparticles. Figure 5 shows the ${ }^{1} \mathrm{H} \rightarrow{ }^{13} \mathrm{C}$ and ${ }^{1} \mathrm{H} \rightarrow{ }^{15} \mathrm{~N}$ CP-MAS NMR spectra of three different lysine samples and two lysine/silica samples. The ${ }^{13} \mathrm{C}$ and ${ }^{15} \mathrm{~N}$ resonance assignments are shown in Table 2. Based on the carbon and nitrogen NMR spectra and Table 2, several conclusions can be drawn. First, lysine has three different protonation states. For natural abundance lysine, it was shown from the $2 \mathrm{D}{ }^{1} \mathrm{H}-$ ${ }^{1} \mathrm{H}$ dipolar DQ/SQ NMR spectrum that the $\varepsilon-\mathrm{NH}_{2}$ is deprotonated and the $\alpha-\mathrm{NH}_{2}$ is protonated (Figure 3). The ${ }^{13} \mathrm{C}$ resonances at $177 \mathrm{ppm}, 55 \mathrm{ppm}$ and $44 \mathrm{ppm}$ were assigned to carboxyl group, $\alpha-\mathrm{CH}$ and $\varepsilon-$ $\mathrm{CH}_{2}$ respectively and the ${ }^{15} \mathrm{~N}$ resonances at $39 \mathrm{ppm}$ and $24 \mathrm{ppm}$ were assigned to $\alpha-\mathrm{NH}_{3}{ }^{+}$and $\varepsilon-\mathrm{NH}_{2}$ respectively based on INADEQUATE and $2 \mathrm{D}{ }^{15} \mathrm{~N}-{ }^{13} \mathrm{C}$ HETCOR NMR experiments, respectively (Figure S2, Figure S3). For ${ }^{13} \mathrm{C},{ }^{15} \mathrm{~N}$-Lysine $\cdot 2 \mathrm{HCl}$, the ${ }^{15} \mathrm{~N}$ resonances of both amine groups have large downfield shifts due to protonation and hydrogen bonding interaction with $\mathrm{Cl}^{-}$. In addition, the ${ }^{13} \mathrm{C}$ resonance of the carboxyl group shifts upfield by $6 \mathrm{ppm}$ to $171 \mathrm{ppm}$, indicating that the carboxyl group is protonated. For ${ }^{13} \mathrm{C},{ }^{15} \mathrm{~N}$-Lysine $\cdot 2 \mathrm{NaCl}$, the ${ }^{13} \mathrm{C}$ resonances of the carboxyl group and $\alpha-\mathrm{CH}$ are identical to those of natural abundance lysine, indicating the carboxyl group is deprotonated and the $\alpha$ $\mathrm{NH}_{2}$ is protonated. However, two resonances are found in $\varepsilon-\mathrm{CH}_{2}$ region with one at $40 \mathrm{ppm}$ and the ACS Paragon Plus Environment 
other at $43 \mathrm{ppm}$, indicating that there is a mixture of protonated and deprotonated components. The proposed structure of each sample is presented in Table 2.

Comparing the lysine spectra with Lysine $/ \mathrm{SiO}_{2}$ spectra, it is found that for both the $\mathrm{Lys} / \mathrm{SiO}_{2}-0.01 \mathrm{M}$ and the ${ }^{13} \mathrm{C},{ }^{15} \mathrm{~N}$-Lysine $/ \mathrm{SiO}_{2}$ the ${ }^{13} \mathrm{C}$ resonances of the carboxyl group and $\alpha-\mathrm{CH}$ and the ${ }^{15} \mathrm{~N}$ resonance of $\alpha-\mathrm{NH}_{2}$ are almost identical to those of natural abundance lysine, indicating the carboxyl group is deprotonated and the $\alpha-\mathrm{NH}_{2}$ is protonated $\left(\alpha-\mathrm{NH}_{3}{ }^{+}\right)$. However, the ${ }^{13} \mathrm{C}$ resonance of $\varepsilon-\mathrm{CH}_{2}$ has an identical value as that of ${ }^{13} \mathrm{C},{ }^{15} \mathrm{~N}$-Lysine $\cdot 2 \mathrm{HCl}$ and ${ }^{15} \mathrm{~N}$ resonance of $\varepsilon-\mathrm{NH}_{2}$ has an 8 ppm downfield shift compared with that of natural abundance lysine, indicating that the $\varepsilon-\mathrm{NH}_{2}$ is protonated, forming a strong hydrogen bonding interaction with the surface silanol groups. To prove this hypothesis, we further applied 2D ${ }^{1} \mathrm{H}_{-}{ }^{13} \mathrm{C}$ HETCOR NMR experiment (Figure 7) to investigate the correlation between silanol groups and adsorbed lysine. The results of the HETCOR NMR experiment are discussed in the preceding paragraph. It is also worth mentioning that one extra resonance at $182 \mathrm{ppm}$ is found in carboxyl group region for ${ }^{13} \mathrm{C},{ }^{15} \mathrm{~N}$-Lysine/ $\mathrm{SiO}_{2}$. This is probably due to a small amount of $\mathrm{NaCl}$ present in the sample, forming a lysine/ $\mathrm{NaCl}$ complex. ${ }^{68}$

The ${ }^{1} \mathrm{H}$ MAS spectra of natural abundance pure lysine and ${ }^{13} \mathrm{C},{ }^{15} \mathrm{~N}-\mathrm{Ly}$ sine/ $\mathrm{SiO}_{2}$ at a MAS speed of $67 \mathrm{kHz}$ are shown in Figure 6. It is found that ${ }^{1} \mathrm{H}$ resonances of $\alpha-\mathrm{CH}$ and $\varepsilon-\mathrm{CH}_{2}$ for adsorbed lysine have small offsets compared to those of bulk lysine. This is probably due to the change of structure and protonation state during the adsorption. The broad resonance at around $7.0 \mathrm{ppm}$ is assigned to the protonated amine groups $\left(\varepsilon-\mathrm{NH}_{3}{ }^{+}\right)$interacting with the surface silanol groups at the silica nanoparticle interface. Figure 7 shows the 2D ${ }^{1} \mathrm{H}-{ }^{13} \mathrm{C}$ HETCOR NMR spectrum of ${ }^{13} \mathrm{C},{ }^{15} \mathrm{~N}$-Lysine/SiO 2 with different CP contact times $(0.25 \mathrm{~ms}, 2.0 \mathrm{~ms})$. Since $2 \mathrm{D}{ }^{1} \mathrm{H}-{ }^{13} \mathrm{C}$ HETCOR NMR experiment is a dipolarbased experiment, where magnetization is transferred through space, long-range correlations can be detected by applying a relatively long $\mathrm{CP}$ contact time. In addition to seeing the expected direct ${ }^{1} \mathrm{H}-{ }^{13} \mathrm{C}$ correlations, the correlation shown around $7.4 \mathrm{ppm}$ in ${ }^{1} \mathrm{H}$ dimension of the spectrum with a $2.0 \mathrm{~ms}$ contact time is assigned to the correlation between silanol group and the $\varepsilon-\mathrm{CH}_{2}$ of adsorbed lysine. This 
result provides strong evidence that the side-chain amine group of adsorbed lysine interacts with silanol groups on silica surfaces.

The ${ }^{13} \mathrm{C},{ }^{15} \mathrm{~N}$-Lysine/ $\mathrm{SiO}_{2}$ sample prepared in this work involves sodium chloride introduced by the $\mathrm{pH}$ adjustment process with $\mathrm{NaOH}$ during adsorption. The $\mathrm{NaCl}$ is difficult to remove since the solubility of lysine in water is similar to that of sodium chloride. To understand if sodium chloride will impact the lysine adsorption on silica surfaces, we carried out several experiments with natural abundance lysine that is initially salt free and applied ${ }^{1} \mathrm{H} \rightarrow{ }^{13} \mathrm{C}$ CP-MAS NMR spectroscopy to characterize the state of adsorbed lysine. The results are shown in Figure 8 for (a) $\mathrm{Lys} / \mathrm{SiO}_{2}-0.01 \mathrm{M}$ sample, (b) $\mathrm{Lys} / \mathrm{SiO}_{2}-0.10 \mathrm{M}$ sample and (c) the sample prepared in a similar way as $\mathrm{Lys} / \mathrm{SiO}_{2}-0.10 \mathrm{M}$ sample with $0.20 \mathrm{M} \mathrm{NaCl}\left(\mathrm{Lys} / \mathrm{SiO}_{2}-0.10 \mathrm{M} / \mathrm{NaCl}\right)$. Based on the NMR results, it is easy to determine that salt free $\mathrm{Lys} / \mathrm{SiO}_{2}-0.10 \mathrm{M}$ sample shows a small peak at $164 \mathrm{ppm}$ that was not observed in the spectra of both $\mathrm{Lys} / \mathrm{SiO}_{2}-0.01 \mathrm{M}$ sample and $\mathrm{Lys} / \mathrm{SiO}_{2}-0.10 \mathrm{M} / \mathrm{NaCl}$ sample. The resonance at $164 \mathrm{ppm}$ is assigned to carbonyl carbon of carbamates since primary amines are known to be able to react with $\mathrm{CO}_{2}$ to form alkyl-ammonium and alkylcarbamates according to a reaction shown in Figure $8 .{ }^{64,69,70}$ The formed carbamates can interact with adsorbed lysine in the salt free system by forming hydrogen bonding with protonated $\alpha-\mathrm{NH}_{3}{ }^{+}$, making it detectable by ${ }^{1} \mathrm{H} \rightarrow{ }^{13} \mathrm{C}$ CP-MAS NMR spectroscopy. The reason why this small resonance is not observed in both $\mathrm{Lys} / \mathrm{SiO}_{2}-0.01 \mathrm{M} / \mathrm{NaCl}$ and $\mathrm{Lys} / \mathrm{SiO}_{2}-$ $0.10 \mathrm{M} / \mathrm{NaCl}$ samples is because lysine molecules form a monolayer on silica nanoparticles while they form multilayers for $\mathrm{Lys} / \mathrm{SiO}_{2}-0.10 \mathrm{M}$. As a result, all amine groups of adsorbed lysine are protonated, preventing them from reacting with $\mathrm{CO}_{2}$ in air. After introducing $\mathrm{NaCl}$ into $\mathrm{Lys} / \mathrm{SiO}_{2}-0.10 \mathrm{M}$, both sodium ions and chloride ions can break the hydrogen bonding system formed by carbamates and $\alpha$ $\mathrm{NH}_{3}{ }^{+}$of adsorbed lysine, making the small peak disappear. This point also agrees with the TGA result where the surface coverage of sample (c) is about 1.60 molecules $/ \mathrm{nm}^{2}$. This is lower than the surface coverage of $\mathrm{Lys} / \mathrm{SiO}_{2}-0.10 \mathrm{M}$ sample (1.82 molecules $\left./ \mathrm{nm}^{2}\right)$. According to these two results, we conclude that sodium chloride decreased the amounts of adsorbed lysine and it prevented lysine from forming 
multilayers on silica surfaces. The sample (c) is in fact a monolayer sample, where the surface coverage of lysine reaches the maximum for monolayer adsorption $\left(\sim 1.60\right.$ molecules $\left./ \mathrm{nm}^{2}\right)$.

DFT Calculation. To elucidate the adsorption state of lysine on silica surfaces and to determine the exact complex structure lysine forms with surface silanol group, we applied DFT calculations. Generally, we optimized structures and calculated the chemical shifts for bulk lysine and a possible lysine/silanol complex determined from NMR experiments (Figure 9). In this work, we extrapolated curves for ${ }^{13} \mathrm{C}$ and ${ }^{15} \mathrm{~N}$ to convert all calculated chemical shielding values to chemical shift values. The extrapolated equation for ${ }^{13} \mathrm{C}$ chemical shifts was derived based on the experimental and calculated ${ }^{13} \mathrm{C}$ chemical shift values of bulk lysine since the structure of bulk lysine was elucidated in this work. Extrapolated equation of ${ }^{15} \mathrm{~N}$ chemical shift was obtained from Alexandra Dos et al's work ${ }^{63,64}$ since they studied the structure of poly-L-lysine systematically by ${ }^{15} \mathrm{~N}$ NMR and DFT calculations. The extrapolated equations of ${ }^{13} \mathrm{C}$ and ${ }^{15} \mathrm{~N}$ chemical shifts are as follows:

$$
\begin{aligned}
& { }^{13} \mathrm{C}: \delta_{\text {Extrapolate }}=-1.123 * \sigma_{\mathrm{Cal}}+206.1 \mathrm{ppm} \\
& { }^{15} \mathrm{~N}: \delta_{\text {Extrapolate }}=-0.778^{*} \sigma_{\mathrm{Cal}}+212.9 \mathrm{ppm}
\end{aligned}
$$

By using these equations, all calculated ${ }^{13} \mathrm{C}$ and ${ }^{15} \mathrm{~N}$ chemical shielding values were converted to chemical shift values and are presented in Table 4. It is found that the $\mathrm{N}-\mathrm{H}$ distance in hydrogen bonding system is $1.807 \AA$ for $\mathrm{Lys}-\mathrm{H}-\mathrm{OSiH}{ }_{3}$, corresponding to hydrogen bonding energy of 42.01 $\mathrm{kJ} / \mathrm{mol}$ (see Table S1). From chemical shift calculations, the $\alpha-\mathrm{NH}_{3}{ }^{+}$protons of bulk lysine have three different chemical shifts at $11.6,1.9,0.5 \mathrm{ppm}$ due to the asymmetry of the protons. After averaging the calculated chemical shifts, the average value $(4.7 \mathrm{ppm})$ is still far off the experiment result. This is probably due to the fact that the $\alpha-\mathrm{NH}_{3}{ }^{+}$group may interact with other groups like carboxylate group and $\mathrm{Cl}^{-}$ions or the model used for calculation is not reliable enough to get reliable $\alpha-\mathrm{NH}_{3}{ }^{+1} \mathrm{H}$ chemical shifts. ${ }^{71}$ For other groups, the ${ }^{1} \mathrm{H}$ chemical shifts are very close to the experimental results. For Lys-H$\mathrm{OSiH}_{3}, \varepsilon-\mathrm{NH}_{3}{ }^{+}$group shows calculated chemical shifts of $7.5,1.1,0.7 \mathrm{ppm}$ where the hydrogen bonding proton has a chemical shift of $7.5 \mathrm{ppm}$. Considering the slow free rotation of the $\varepsilon-\mathrm{NH}_{3}{ }^{+}$group due to the strong hydrogen binding, the calculation result is consistent with experimental result (7.4 ppm). ACS Paragon Plús Environment 
Moreover, the calculated ${ }^{13} \mathrm{C}$ chemical shift of $\varepsilon-\mathrm{CH}_{2}$ for $\mathrm{Lys}-\mathrm{H}-\mathrm{OSiH} \mathrm{H}_{3}$ is only 1 ppm off the experimental data and the calculated ${ }^{15} \mathrm{~N}$ chemical shift of $\alpha-\mathrm{NH}_{3}{ }^{+}$and $\varepsilon-\mathrm{NH}_{3}{ }^{+}$have 2 ppm and 4 ppm off the experimental data respectively for $\mathrm{Lys}_{-} \mathrm{H}-\mathrm{OSiH} \mathrm{H}_{3}$. Combining the calculated and experimental results, it is convincing to argue that the lysine side-chain amine group is the dominant hydrogenbonding interaction with surface silanol groups at silica nanoparticles and $\mathrm{Lys}-\mathrm{H}-\mathrm{OSiH}_{3}$ complex is the most probable structure. Combined with NMR experiment results, the proposed favorable model for lysine adsorption on fume silica nanoparticles surfaces is presented in Figure 9.

\section{CONCLUSION}

The structure of bulk lysine and lysine adsorbed on fumed silica nanoparticles were thoroughly investigated by ultrafast MAS ${ }^{1} \mathrm{H},{ }^{13} \mathrm{C}$ and ${ }^{15} \mathrm{~N}$ solid-state NMR spectroscopy. Bulk L-lysine has protonated $\alpha-\mathrm{NH}_{3}{ }^{+}$and deprotonated $\varepsilon-\mathrm{NH}_{2}$. Lysine adsorbed on fumed silica nanoparticles from solution interacts with silica surfaces through hydrogen bonding between side-chain amine groups and surface silanol groups. Combined with DFT calculations, we further proposed that the $\mathrm{Lys}-\mathrm{H}-\mathrm{OSiH}$ complex is the favorable model for the lysine adsorption state on silica surfaces. The proposed model can be used to elucidate the mechanism of synthesizing ultra-small silica nanoparticles $(\sim 10 \mathrm{~nm})$ with lysine as capping ligands and it is of use to researchers interested in surface functionalization and modification. Also, the agreement of DFT calculations of NMR chemical shifts with the corresponding experimental values is good in general, which means the combination of solid-state NMR and DFT chemical shift calculations can indeed be used to study surface chemistry at the interface of biomolecules and nanoparticles.

\section{ASSOCIATED CONTENT}

\section{Supporting Information}

${ }^{1} \mathrm{H}-{ }^{13} \mathrm{C}$ HETCOR NMR spectrum of bulk lysine, 2D ${ }^{13} \mathrm{C}-{ }^{13} \mathrm{C}$ INADEQUATE NMR spectrum of ${ }^{13} \mathrm{C}$, ${ }^{15} \mathrm{~N}$-Lysine $\cdot 2 \mathrm{HCl},{ }^{15} \mathrm{~N}-{ }^{13} \mathrm{C}$ 2D HETCOR NMR spectrum of ${ }^{13} \mathrm{C},{ }^{15} \mathrm{~N}-$-lysine/SiO $2,2 \mathrm{D}{ }^{13} \mathrm{C}-{ }^{13} \mathrm{C}$ throughspace correlation NMR spectrum of ${ }^{13} \mathrm{C},{ }^{15} \mathrm{~N}$-Lysine $\cdot 2 \mathrm{HCl}$, Extrapolated curve of ${ }^{13} \mathrm{C}$ chemical shift and 
Summary of Lysine/Silanol Complex from DFT Calculations. This materials is available free of charge via the Internet at http://pubs.acs.org

\section{AUTHOR INFORMATION}

\section{Corresponding Author}

*E-mail: gholland@mail.sdsu.edu,jyarger@gmail.com

\section{Notes}

The authors declare no competing financial interest.

\section{Acknowledgment.}

The research was supported by grants from the National Science Foundation (CHE-1011937). We thank Dr. Brian Cherry for help with NMR instrumentation, student training, and scientific discussion.

\section{REFERENCES:}

(1) Lambert, J. F. Adsorption and Polymerization of Amino Acids on Mineral Surfaces: a Review. Origins Life Evol. B. 2008, 38, 211-242.

(2) Lambert, J. F.; Stievano, L.; Lopes, I.; Gharsallah, M.; Piao, L. The Fate of Amino Acids Adsorbed on Mineral Matter. Planet. Space Sci. 2009, 57, 460-467.

(3) Zaia, D. A. M. A Review of Adsorption of Amino Acids on Minerals: Was It Important for Origin of Life? Amino Acids 2004, 27, 113-118.

(4) Tarn, D.; Ashley, C. E.; Xue, M.; Carnes, E. C.; Zink, J. I.; Brinker, C. J. Mesoporous Silica Nanoparticle Nanocarriers: Biofunctionality and Biocompatibility. Acc. Chem. Res. 2013, 46, 792-801.

(5) Malfatti, M. A.; Palko, H. A.; Kuhn, E. A.; Turteltaub, K. W. Determining the Pharmacokinetics and Long-Term Biodistribution of $\mathrm{SiO}_{2}$ Nanoparticles in Vivo Using Accelerator Mass Spectrometry. Nano Lett. 2012, 12, 55325538.

(6) Zhang, H.; Dunphy, D. R.; Jiang, X.; Meng, H.; Sun, B.; Tarn, D.; Xue, M.; Wang, X.; Lin, S.; Ji, Z.; et al. Processing Pathway Dependence of Amorphous Silica Nanoparticle Toxicity: Colloidal vs Pyrolytic. J. Am. Chem. Soc. 2012, 134, 15790-15804.

(7) Graf, C.; Gao, Q.; Schütz, I.; Noufele, C. N.; Ruan, W.; Posselt, U.; Korotianskiy, E.; Nordmeyer, D.; Rancan, F.; Hadam, S.; et al. Surface Functionalization of Silica Nanoparticles Supports Colloidal Stability in Physiological Media and Facilitates Internalization in Cells. Langmuir 2012, 28, 7598-7613. 
(8) Ashley, C. E.; Carnes, E. C.; Epler, K. E.; Padilla, D. P.; Phillips, G. K.; Castillo, R. E.; Wilkinson, D. C.;

Wilkinson, B. S.; Burgard, C. A.; Kalinich, R. M.; et al. Delivery of Small Interfering RNA by Peptide-Targeted Mesoporous Silica Nanoparticle-Supported Lipid Bilayers. ACS Nano 2012, 6, 2174-2188.

(9) Patwardhan, S. V.; Emami, F. S.; Berry, R. J.; Jones, S. E.; Naik, R. R.; Deschaume, O.; Heinz, H.; Perry, C. C. Chemistry of Aqueous Silica Nanoparticle Surfaces and the Mechanism of Selective Peptide Adsorption. J. Am. Chem. Soc. 2012, 134, 6244-6256.

(10) Hubbell, J. A.; Chilkoti, A. Nanomaterials for Drug Delivery. Science 2012, 337, 303-305.

(11) Ashley, C. E.; Carnes, E. C.; Phillips, G. K.; Padilla, D.; Durfee, P. N.; Brown, P. A.; Hanna, T. N.; Liu, J.;

Phillips, B.; Carter, M. B.; et al. The Targeted Delivery of Multicomponent Cargos to Cancer Cells by Nanoporous Particle-Supported Lipid Bilayers. Nat. Mater. 2011, 10, 389-397.

(12) Liu, J.; Stace-Naughton, A.; Jiang, X.; Brinker, C. J. Porous Nanoparticle Supported Lipid Bilayers (Protocells) as Delivery Vehicles. J. Am. Chem. Soc. 2009, 131, 1354-1355.

(13) Vallet-Regi, M.; Rámila, A.; del Real, R. P.; Perez-Pariente, J. A New Property of MCM-41: Drug Delivery System. Chem. Mater. 2001, 13, 308-311.

(14) Lu, J.; Liong, M.; Zink, J. I.; Tamanoi, F. Mesoporous Silica Nanoparticles as a Delivery System for Hydrophobic Anticancer Drugs. Small 2007, 3, 1341-1346.

(15) Orgel, L. E. Polymerization on the Rocks: Theoretical Introduction. Origins Life Evol. B. 1998, 28, 227-234.

(16) Rimola, A.; Costa, D.; Sodupe, M.; Lambert, J. F.; Ugliengo, P. Silica Surface Features and Their Role in the Adsorption of Biomolecules: Computational Modeling and Experiments. Chem. Rev. 2013, 113, 4216-4313.

(17) Liu, C. C.; Maciel, G. E. The Fumed Silica Surface: a Study by NMR. J. Am. Chem. Soc. 1996, 118, 5103-5119.

(18) McDonald, R. S. Surface Functionality of Amorphous Silica by Infrared Spectroscopy. J. Phys. Chem 1958, 62, $1168-1178$.

(19) Morrow, B. A.; McFarian, A. J. Surface Vibrational Modes of Silanol Groups on Silica. J. Phys. Chem 1992, 96 , 1395-1400.

(20) Gunko, V. M.; Voronin, E. F.; Pakhlov, E. M.; Zarko, V. I.; Turov, V. V.; Guzenko, N. V.; Leboda, R. Features of Fumed Silica Coverage with Silanes Having Three or Two Groups Reacting with the Surface. Coll. Surf. A 2000, $166,187-201$.

(21) Bakaev, V. A.; Pantano, C. G. Inverse Reaction Chromatography. 2. Hydrogen/Deuterium Exchange with Silanol Groups on the Surface of Fumed Silica. J. Phys. Chem. C 2009, 113, 13894-13898.

(22) Peng, L.; Qisui, W.; Xi, L.; Chaocan, Z. Investigation of the States of Water and OH Groups on the Surface of Silica. Coll. Surf. A 2009, 334, 112-115. 
(23) Tielens, F.; Gervais, C.; Lambert, J. F.; Mauri, F.; Costa, D. Ab Initio Study of the Hydroxylated Surface of Amorphous Silica: a Representative Model. Chem. Mater. 2008, 20, 3336-3344.

(24) Aboshi, A.; Kurumoto, N.; Yamada, T.; Uchino, T. Influence of Thermal Treatments on the Photoluminescence Characteristics of Nanometer-Sized Amorphous Silica Particles. J. Phys. Chem. C 2007, 111, 8483-8488.

(25) Brei, V. V. ${ }^{29}$ Si Solid-State NMR Study of the Surface Structure of Aerosil Silica. J. Chem. Soc Faraday Trans. 1994, 90, 2961-2964.

(26) Tomczak, M. M.; Glawe, D. D.; Drummy, L. F.; Lawrence, C. G.; Stone, M. O.; Perry, C. C.; Pochan, D. J.; Deming, T. J.; Naik, R. R. Polypeptide-Templated Synthesis of Hexagonal Silica Platelets. J. Am. Chem. Soc. 2005, 127, 12577-12582.

(27) Yokoi, T.; Sakamoto, Y.; Terasaki, O.; Kubota, Y.; Okubo, T.; Tatsumi, T. Periodic Arrangement of Silica Nanospheres Assisted by Amino Acids. J. Am. Chem. Soc. 2006, 128, 13664-13665.

(28) Yokoi, T.; Wakabayashi, J.; Otsuka, Y.; Fan, W.; Iwama, M.; Watanabe, R.; Aramaki, K.; Shimojima, A.; Tatsumi, T.; Okubo, T. Mechanism of Formation of Uniform-Sized Silica Nanospheres Catalyzed by Basic Amino Acids. Chem. Mater. 2009, 21, 3719-3729.

(29) Behrens, S. H.; Grier, D. G. The Charge of Glass and Silica Surfaces. J. Chem. Phys. 2001, 115, 6716-6721. (30) Roddick-Lanzilotta, A. D.; Connor, P. A.; McQuillan, A. J. An in Situ Infrared Spectroscopic Study of the Adsorption of Lysine to $\mathrm{TiO}_{2}$ From an Aqueous Solution. Langmuir 1998, 14, 6479-6484.

(31) Kitadai, N.; Yokoyama, T.; Nakashima, S. In Situ ATR-IR Investigation of L-Lysine Adsorption on Montmorillonite. J. Colloid Interface Sci. 2009, 338, 395-401.

(32) Wright, D. A.; Marsh, R. E. The Crystal Structure of L-Lysine Monohydrochloride Dihydrate. Acta Cryst 1962, 15, $54-64$.

(33) Koetzle, T. F.; Lehmann, M. S.; Verbist, J. J.; Hamilton, W. C. Precision Neutron Diffraction Structure Determination of Protein and Nucleic Acid Components. VII. the Crystal and Molecular Structure of the Amino Acid L-Lysine Monohydrochloride Dihydrate. Acta Cryst 1972, B28, 3207-3214.

(34) Ben Shir, I.; Kababya, S.; Schmidt, A. Binding Specificity of Amino Acids to Amorphous Silica Surfaces: SolidState NMR of Glycine on SBA-15. J. Phys. Chem. C 2012, 116, 9691-9702.

(35) Amitay-Rosen, T.; Vega, S. A Deuterium MAS NMR Study of the Local Mobility of Dissolved Methionine and Di-Alanine at the Inner Surface of SBA-15. Phys. Chem. Chem. Phys. 2010, 12, 6763-6773.

(36) Amitay-Rosen, T.; Kababya, S.; Vega, S. A Dynamic Magic Angle Spinning NMR Study of the Local Mobility of Alanine in an Aqueous Environment at the Inner Surface of Mesoporous Materials. J. Phys. Chem. B 2009, 113, $6267-6282$. 
(37) Gao, Q.; Xu, W.; Xu, Y.; Wu, D.; Sun, Y.; Deng, F.; Shen, W. Amino Acid Adsorption on Mesoporous Materials: Influence of Types of Amino Acids, Modification of Mesoporous Materials, and Solution Conditions. $J$. Phys. Chem. B 2008, 112, 2261-2267.

(38) Stievano, L.; Yu Piao, L.; Lopes, I.; Meng, M.; Costa, D.; Lambert, J. F. Glycine and Lysine Adsorption and Reactivity on the Surface of Amorphous Silica. Eur. J. Mineral. 2007, 19, 321-331.

(39) Meng, M.; Stievano, L.; Lambert, J. F. Adsorption and Thermal Condensation Mechanisms of Amino Acids on Oxide Supports. 1. Glycine on Silica. Langmuir 2004, 20, 914-923.

(40) Lopes, I.; Piao, L.; Stievano, L.; Lambert, J. F. Adsorption of Amino Acids on Oxide Supports: a Solid-State NMR Study of Glycine Adsorption on Silica and Alumina. J. Phys. Chem. C 2009, 113, 18163-18172.

(41) Kitadai, N.; Yokoyama, T.; Nakashima, S. ATR-IR Spectroscopic Study of L-Lysine Adsorption on Amorphous Silica. J. Colloid Interface Sci. 2009, 329, 31-37.

(42) O’Connor, A. J.; Hokura, A.; Kisler, J. M.; Shimazu, S.; Stevens, G. W.; Komatsu, Y. Amino Acid Adsorption Onto Mesoporous Silica Molecular Sieves. Sep. Purif. Technol. 2006, 48, 197-201.

(43) Dybowski, C.; Bai, S. Solid-State NMR Spectroscopy. Anal. Chem. 2008, 80, 4295-4300.

(44) Ben Shir, I.; Kababya, S.; Amitay-Rosen, T.; Balazs, Y. S.; Schmidt, A. Molecular Level Characterization of the Inorganic-Bioorganic Interface by Solid State NMR: Alanine on a Silica Surface, a Case Study. J. Phys. Chem. B 2010, 114, 5989-5996.

(45) Mirau, P. A.; Serres, J. L.; Lyons, M. The Structure and Dynamics of Poly( L-Lysine) in Templated Silica Nanocomposites. Chem. Mater. 2008, 20, 2218-2223.

(46) Gullion, T.; Schaefer, J. Rotational-Echo Double-Resonance NMR. J. Magn. Reson. 1989, 81, 196-200.

(47) Andrew, E. R. The Narrowing of NMR Spectra of Solids by High-Speed Specimen Rotation and the Resolution of Chemical Shift and Spin Multiplet Structures for Solids. Prog. Nucl. Magn. Reson. Spectrosc. 1971, 8, 1-39.

(48) Kohn, P. H. A. W. Inhomogeneous Electron Gas. Phys. Rev. 1964, 136, 864-871.

(49) Sham, W. K. A. L. J. Self-Consistent Equations Including Exchange and Correlation Effects. Phys. Rev. 1965, 140, $1133-1138$.

(50) Hahn, S. R. H. A. E. L. Nuclear Double Resonance in the Rotating Frame. Phys. Rev. 1962, 128, $2042-2053$.

(51) Meier, B. H. Cross Polarization Under Fast Magic Angle Spinning: Thermodynamical Considerations. Chem. Phys. Lett. 1992, 18, 201-207.

(52) Takegoshi, K.; Nakamura, S.; Terao, T. ${ }^{13} \mathrm{C}-{ }^{1} \mathrm{H}$ Dipolar-Assisted Rotational Resonance in Magic-Angle Spinning NMR. Chem. Phys. Lett. 2001, 344, 631-637.

(53) Takegoshi, K.; Nakamura, S.; Terao, T. ${ }^{13} \mathrm{C}-{ }^{1} \mathrm{H}$ Dipolar-Driven ${ }^{13} \mathrm{C}-{ }^{13} \mathrm{C}$ Recoupling Without ${ }^{13} \mathrm{C}$ RF Irradiation in ACS Paragon Plús Environment 
Nuclear Magnetic Resonance of Rotating Solids. J. Chem. Phys. 2003, 118, 2325-2341.

(54) Lesage, A.; Auger, C.; Caldarelli, S.; Emsley, L. Determination of Through-Bond Carbon-Carbon Connectivities in Solid-State NMR Using the INADEQUATE Experiment. J. Am. Chem. Soc. 1997, 119, 7867-7868.

(55) Lesage, A.; Bardet, M.; Emsley, L. Through-Bond Carbon-Carbon Connectivities in Disordered Solids by NMR. J. Am. Chem. Soc. 1999, 121, 10987-10993.

(56) Bennett, A. E.; Rienstra, C. M.; Auger, M.; Lakshmi, K. V.; Griffin, R. G. Heteronuclear Decoupling in Rotating Solids. J. Chem. Phys. 1995, 103, 6951-6958.

(57) Feike, M.; Demco, D. E.; Graf, R.; Gottwald, J.; Hafner, S.; Spiess, H. W. Broadband Multiple-Quantum NMR Spectroscopy. J. Magn. Reson. A 1996, 122, 214-221.

(58) Feike, M.; Graf, R.; Schnell, I.; Jager, C.; Spiess, H. W. Structure of Crystalline Phosphates From ${ }^{31}$ P DoubleQuantum NMR Spectroscopy. J. Am. Chem. Soc. 1996, 118, 9631-9634.

(59) Schnell, I.; Spiess, H. W. High-Resolution ${ }^{1}$ H NMR Spectroscopy in the Solid State: Very Fast Sample Rotation and Multiple-Quantum Coherences. J. Magn. Reson. 2001, 151, 153-227.

(60) Hayashi, S.; Hayamizu, K. Chemical Shift Standards in High-Resolution Solid-State NMR (1) ${ }^{13} \mathrm{C},{ }^{29} \mathrm{Si}$, and ${ }^{1} \mathrm{H}$ Nuclei. Bull. Chem. Soc. Jpn. 1991, 64, 685-687.

(61) Hayashi, S.; Hayamizu, K. Chemical Shift Standards in High-Resolution Solid-State NMR (2) ${ }^{15}$ N Nuclei. Bull. Chem. Soc. Jpn. 1991, 64, 688-690.

(62) Becke, A. D. Density-Functional Thermochemistry. III. the Role of Exact Exchange. J. Chem. Phys. 1993, 98, $5648-5652$.

(63) Dos, A.; Schimming, V.; Huot, M. C.; Limbach, H. H. Acid-Induced Amino Side-Chain Interactions and Secondary Structure of Solid Poly- L-Lysine Probed by ${ }^{15} \mathrm{~N}$ and ${ }^{13} \mathrm{C}$ Solid State NMR and Ab Initio Model Calculations. J. Am. Chem. Soc. 2009, 131, 7641-7653.

(64) Dos, A.; Schimming, V.; Tosoni, S.; Limbach, H. H. Acid-Base Interactions and Secondary Structures of Poly- LLysine Probed by ${ }^{15} \mathrm{~N}$ and ${ }^{13} \mathrm{C}$ Solid State NMR and Ab Initio Model Calculations. J. Phys. Chem. B 2008, 112, $15604-15615$.

(65) Rimola, A.; Sodupe, M.; Ugliengo, P. Affinity Scale for the Interaction of Amino Acids with Silica Surfaces. $J$. Phys. Chem. C 2009, 113, 5741-5750.

(66) Wolinski, K.; Hinton, J. F.; Pulay, P. Efficient Implementation of the Gauge-Independent Atomic Orbital Method for NMR Chemical Shift Calculations. J. Am. Chem. Soc. 1990, 112, 8251-8260.

(67) Schreckenbach, G.; Ziegler, T. Calculation of NMR Shielding Tensors Using Gauge-Including Atomic Orbitals and Modern Density Functional Theory. J. Phys. Chem 1995, 99, 606-611.

\section{ACS Paragon Plus Environment}


1

2

3

4

5

6

7

8

9

10

11

12

13

14

15

16

17

(68) Manríquez, R.; López-Dellamary, F. A.; Frydel, J.; Emmler, T.; Breitzke, H.; Buntkowsky, G.; Limbach, H. H.; Shenderovich, I. G. Solid-State NMR Studies of Aminocarboxylic Salt Bridges in L-Lysine Modified Cellulose. $J$. Phys. Chem. B 2009, 113, 934-940.

(69) Maeda, S.; Oumae, S.; Kaneko, S.; Kunimoto, K.-K. Formation of Carbamates and Cross-Linking of Microbial Poly(E-L-Lysine) Studied by ${ }^{13} \mathrm{C}$ and ${ }^{15} \mathrm{~N}$ Solid-State NMR. Polym. Bull. 2011, 68, 745-754.

(70) Schimming, V.; Hoelger, C. G.; Buntkowsky, G.; Sack, I.; Fuhrhop, J. H.; Rocchetti, S.; Limbach, H. H. Evidence by ${ }^{15} \mathrm{~N}$ CPMAS and ${ }^{15} \mathrm{~N}-{ }^{13} \mathrm{C}$ REDOR NMR for Fixation of Atmospheric $\mathrm{CO}_{2}$ By Amino Groups of Biopolymers in the Solid State. J. Am. Chem. Soc. 1999, 121, 4892-4893.

(71) Schmidt, J.; Hoffmann, A.; Spiess, H. W.; Sebastiani, D. Bulk Chemical Shifts in Hydrogen-Bonded Systems From First-Principles Calculations and Solid-State-NMR. J. Phys. Chem. B 2006, 110, 23204-23210. 
Table 1. Effect of Initial Concentration of Solution on Lysine Adsorption on Fumed Silica Nanoparticles from TGA

2

3

4

5

6

7

8

9

10

11

12

13

14

15

16

17

18

19

20

21

22

23

24

25

26

27

28

29

30

31

32

33

34

35

36

37

38

39

40

41

42

43

44

45

46

47

48

49

50

51

52

53

54

55

56

57

58

59

60

\begin{tabular}{ccccc}
\hline \hline [Lysine] & $\begin{array}{c}\text { Free water } \\
\text { (wt \%) }\end{array}$ & $\begin{array}{c}\text { Lysine } \\
\text { (wt \%) }\end{array}$ & $\begin{array}{c}\text { Total adsorbed } \\
\text { amount (wt \%) }\end{array}$ & $\begin{array}{c}\text { Surface coverage } \\
\text { (molecules/nm }{ }^{2} \text { ) }\end{array}$ \\
\hline $0.01 \mathrm{M}$ & 1.16 & 5.85 & 7.01 & 0.7 \\
$0.03 \mathrm{M}$ & 1.39 & 9.06 & 10.45 & 1.1 \\
$0.05 \mathrm{M}$ & 1.13 & 11.85 & 12.98 & 1.4 \\
$0.08 \mathrm{M}$ & 1.34 & 13.51 & 14.85 & 1.7 \\
$0.10 \mathrm{M}$ & 1.63 & 14.62 & 16.25 & 1.8 \\
$0.12 \mathrm{M}$ & 1.48 & 15.99 & 17.47 & 2.0 \\
$0.15 \mathrm{M}$ & 2.12 & 17.74 & 19.86 & 2.3 \\
\hline \hline
\end{tabular}

\section{Table 1}


Table $2 .{ }^{13} \mathrm{C}$ and ${ }^{15} \mathrm{~N}$ Chemical Shifts of Lysine and Lysine/SiO ${ }_{2}$ Samples a

2

3

4

5

6

7

8

9

10

11

12

13

14

15

16

17

18

19

20

21

22

23

24

25

26

27

28

29

30

31

32

33

34

35

36

37

38

39

40

41

42

43

44

45

46

47

48

49

50

51

52

53

54

55

56

57

58

59

60

\section{Table 2}


Table 3. Calculated ${ }^{1} \mathrm{H},{ }^{13} \mathrm{C}$ and ${ }^{15} \mathrm{~N}$ Chemical Shielding Values and Extrapolated Chemical Shifts for Lysine and Lysine/silanol Complex from DFT Calculations ${ }^{a}$

\begin{tabular}{|c|c|c|c|c|c|c|}
\hline & & \multicolumn{2}{|c|}{ Lysine } & \multicolumn{3}{|c|}{$\mathrm{LysH}^{+\ldots-\mathrm{OSiH}_{3}}$} \\
\hline & & Calculated & Experiment & Calculated & Extrapolated & Experiment \\
\hline \multirow{6}{*}{${ }^{13} \mathrm{C}$} & $\mathrm{C}=0$ & 26.0 & 177 & 26.0 & 177 & 177 \\
\hline & $\alpha-\mathrm{CH}$ & 133.0 & 55 & 133.2 & 57 & 55 \\
\hline & $\beta-\mathrm{CH}_{2}$ & 154.3 & 35 & 154.5 & 33 & 30 \\
\hline & $\gamma-\mathrm{CH}_{2}$ & 162.2 & 22 & 162.4 & 24 & 23 \\
\hline & $\delta-\mathrm{CH}_{2}$ & 155.4 & 32 & 158.4 & 28 & 27 \\
\hline & $\varepsilon-\mathrm{CH}_{2}$ & 145.3 & 44 & 146.7 & 41 & 40 \\
\hline \multirow{2}{*}{${ }^{15} \mathrm{~N}$} & $\alpha-\mathrm{NH}_{3}{ }^{+}$ & 226.3 & 39 & 226.7 & 37 & 39 \\
\hline & $\varepsilon-\mathrm{NH}_{2} / \varepsilon-\mathrm{NH}_{3}{ }^{+}$ & 232.7 & 24 & 227.8 & 36 & 32 \\
\hline \multirow{7}{*}{${ }^{1} \mathbf{H}$} & $\alpha-\mathrm{CH}$ & 2.8 & $\overline{3.6}$ & 2.8 & - & 3.6 \\
\hline & $\beta-\mathrm{CH}_{2}$ & 1.8 & 1.8 & 1.8 & - & 1.5 \\
\hline & $\gamma-\mathrm{CH}_{2}$ & 1.2 & 1.5 & 1.2 & - & 1.2 \\
\hline & $\delta-\mathrm{CH}_{2}$ & 1.5 & 2.0 & 1.6 & - & 1.5 \\
\hline & $\varepsilon-\mathrm{CH}_{2}$ & 2.8 & 2.2 & 2.7 & - & 2.6 \\
\hline & $\alpha-\mathrm{NH}_{3}{ }^{+}$ & $11.6,1.9,0.5$ & 8.4 & $11.6,1.9,0.6$ & - & 8.4 \\
\hline & $\varepsilon-\mathrm{NH}_{2} / \varepsilon-\mathrm{NH}_{3}{ }^{+}$ & 0.7 & - & $7.5,1.1,0.7$ & - & 7.4 \\
\hline
\end{tabular}

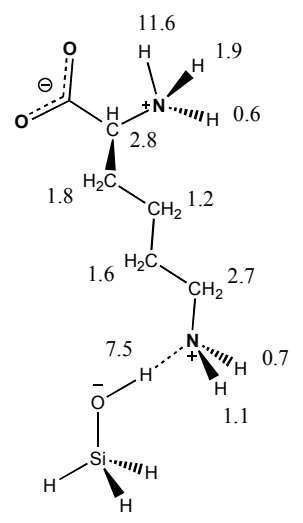

${ }^{\mathrm{a}}$ Chemical shifts are reported in ppm.

\section{Table 3}


1

2

3

4

5

6

7

8

9

10

11

12

13

14

15

16

17

18

19

20

21

22

23

24

25

26

27

28

29

30

31

32

33

34

35

36

37

38

39

40

41

42

43

44

45

46

47

48

49

50

51

52

53

54

55

56

57

58

59

60

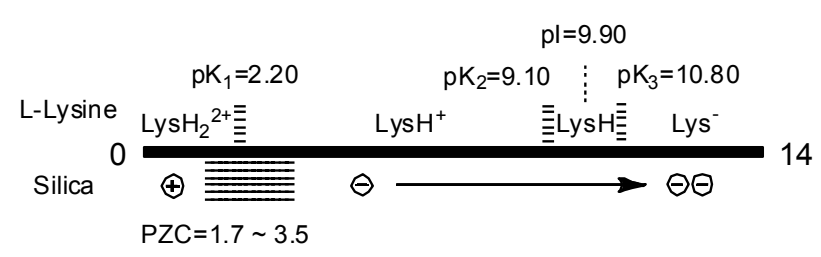

Lysh $_{2}{ }^{2+}:{ }^{+} \mathrm{H}_{3} \mathrm{~N} \underbrace{\mathrm{OH}}_{\mathrm{NH}_{3}^{+}}$(Dicationic Form)

LysH $^{+}:{ }^{+} \mathrm{H}_{3} \mathrm{~N}$

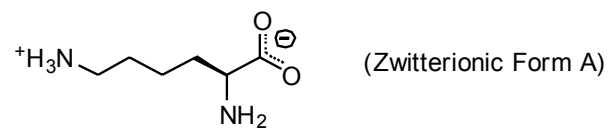

LysH :

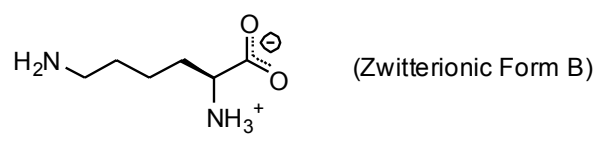

Lys ${ }^{-}$:

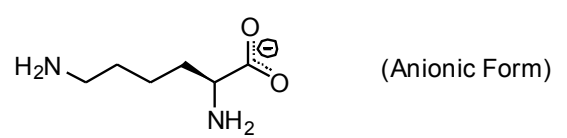

Figure 1 

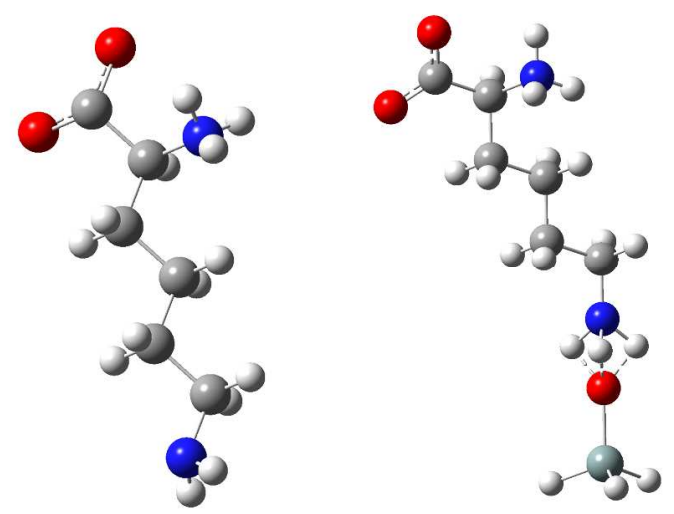

(A)

(B)

\section{Figure 2}

33

34

35

36

37

38

39

40

41

42

43

44

45

46

47

48

49

50

51

52

53

54

55

56

57

58

59

60 
1

2

3

4

5

6

7

8

9

10

11

12

13

14

15

16

17

18

19

20

21

22

23

24

25

26

27

28

29

30

31

32

33

34

35

36

37

38

39

40

41

42

43

44

45

46

47

48

49

50

51

52

53

54

55

56

57

58

59

60
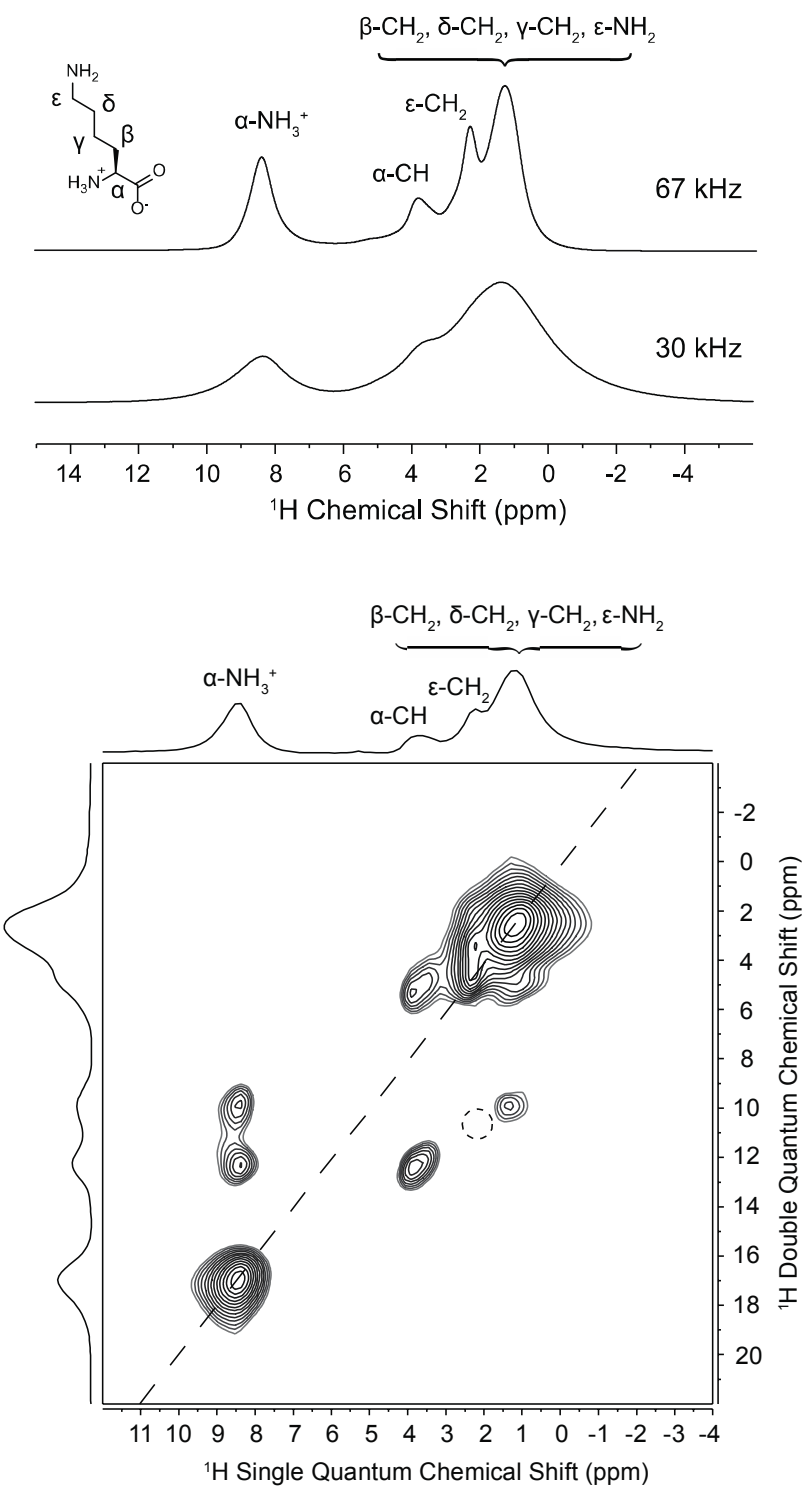

Figure 3

ACS Paragon Plus Environment 
39

40

41

42

43

44

45

46

47

48

49

50

51

52

53

54

55

56

57

58

59

60
(A)

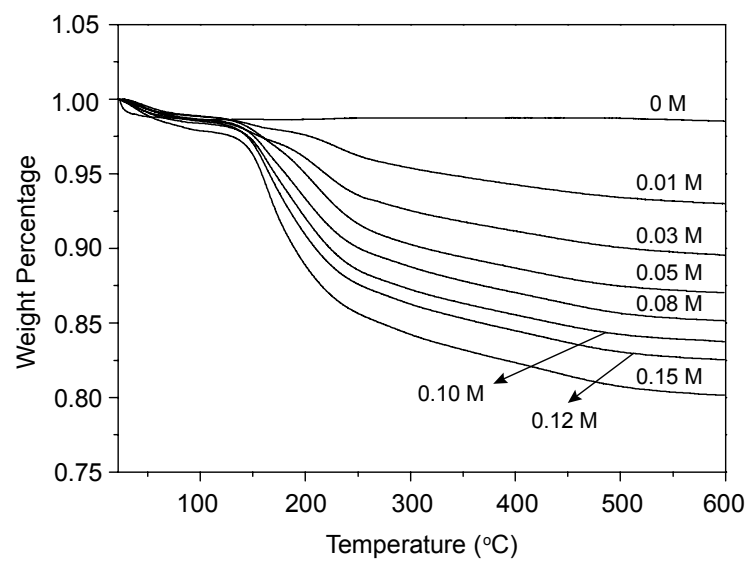

(B)

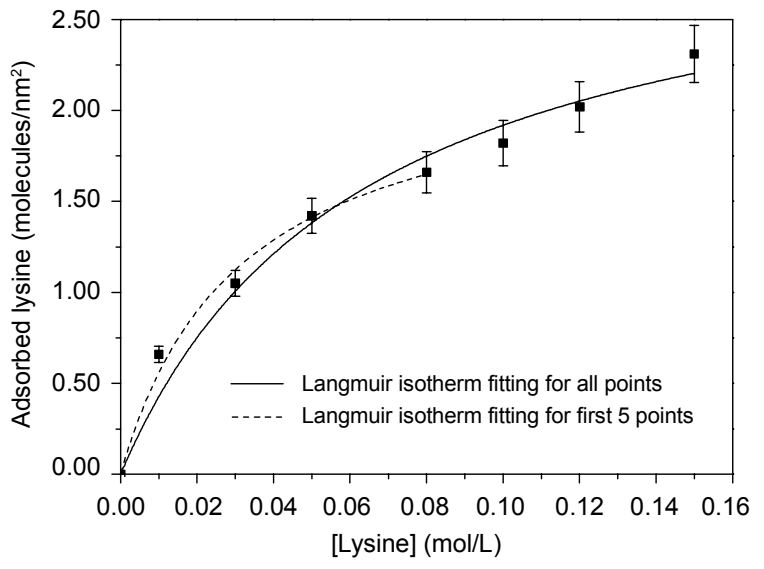

\section{Figure 4}


1

2

3

4

5

6

7

10

11

12

13

14

15

16

17

18

19

20

21

22

23

24

25

26

27

28

29

30

31

32

33

34

35

36

37

38

39

40

41

42

43

44

45

46

47

48

49

50

51

52

53

54

55

56

57

58

59

60
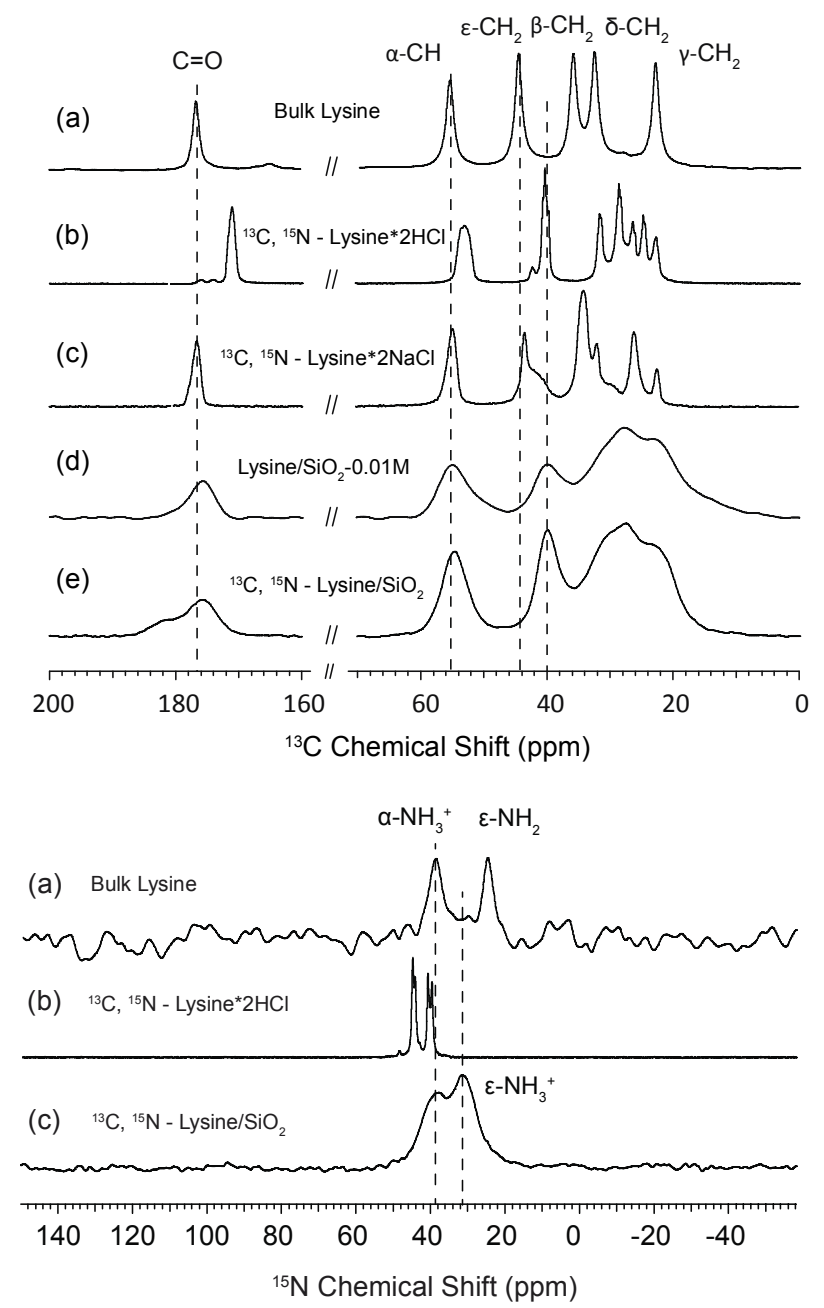

Figure 5 


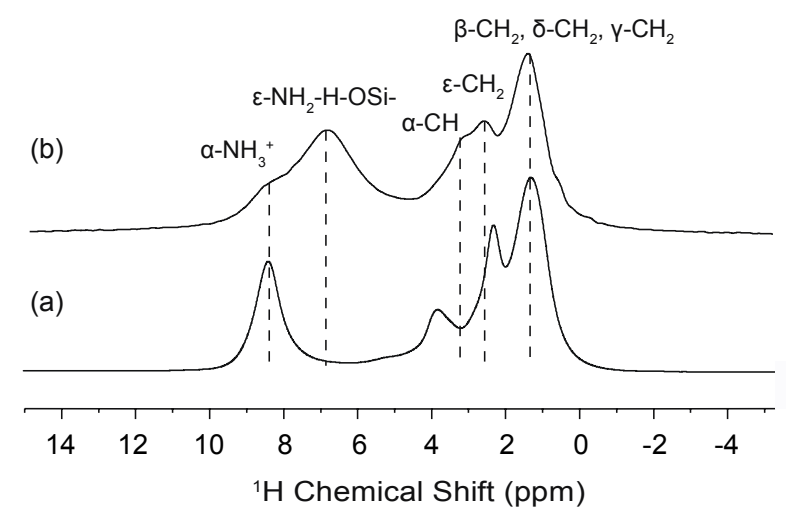

\section{Figure 6}




\section{Figure 7}

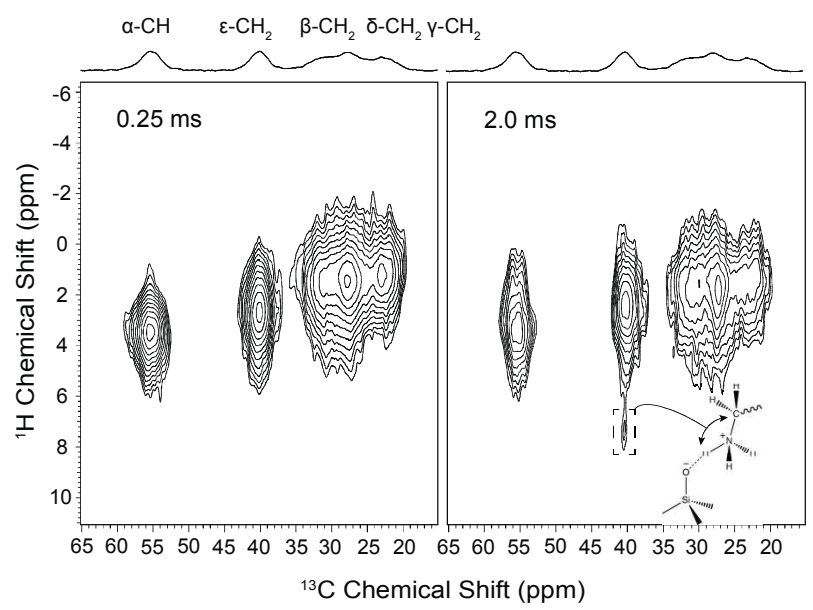




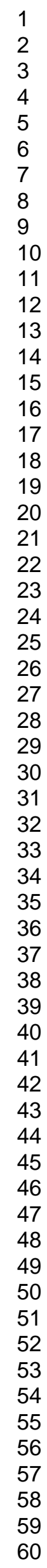
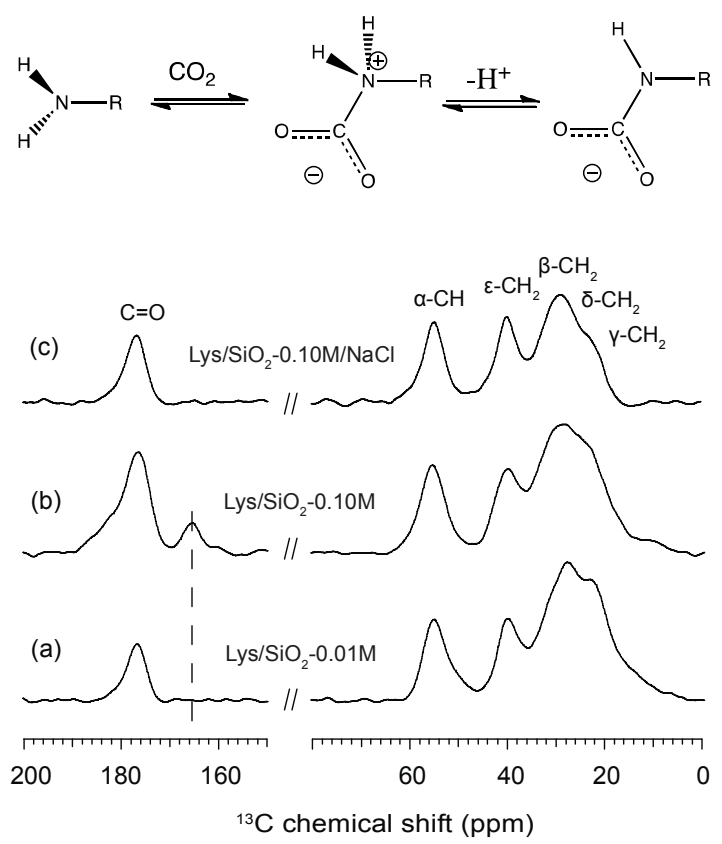

Figure 8 
1

2

3

4

5

6

7

8

9

10

11

12

13

14

15

16

17

18

19

20

21

22

23

24

25

26

27

28

29

30

31

32

33

34

35

36

37

38

39

40

41

42

43

44

45

46

47

48

49

50

51

52

53

54

55

56

57

58

59

60

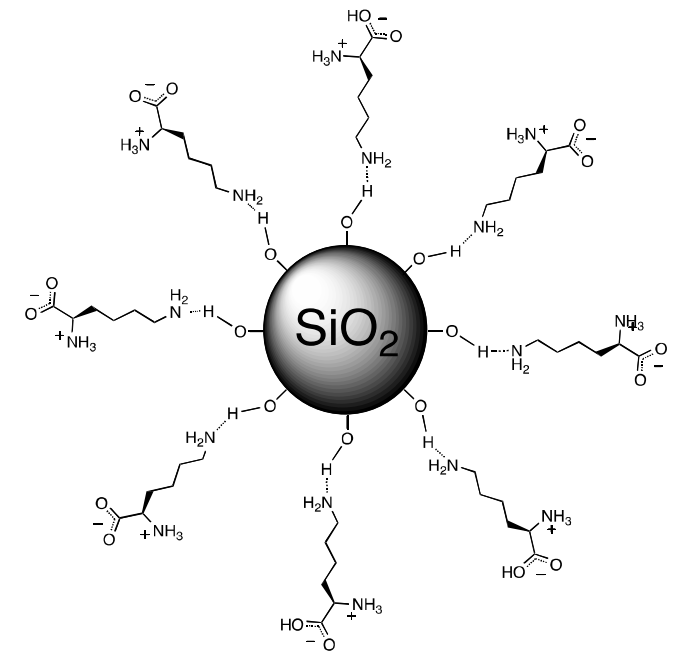

\section{Figure 9}




\section{Figure Captions}

Figure 1. Summary of different L-lysine forms and charged states of silica surface as a function of $\mathrm{pH}$ values. ${ }^{41}$

Figure 2. Bulk lysine and lysine/silanol complex models used in DFT calculations: A) Lysine, B) Lys-H-OSiH . $_{3}$

Figure 3. A) ${ }^{1} \mathrm{H}$ NMR spectra of natural abundance bulk lysine at MAS speeds of $30 \mathrm{kHz}$ and $67 \mathrm{kHz}$ at a ${ }^{1} \mathrm{H}$ Larmor frequency of 800 MHz and $850 \mathrm{MHz}$, respectively. B) ${ }^{1} \mathrm{H}-{ }^{1} \mathrm{H}$ BABA NMR spectrum of natural abundance bulk lysine at spinning speed of $67 \mathrm{kHz}$ at a ${ }^{1} \mathrm{H}$ Larmor frequency of $850 \mathrm{MHz}$.

Figure 4. A) TGA curves of lysine/silica samples as a function of initial concentration of lysine in the adsorption solution. B) The amount of lysine adsorbed on silica as a function of initial concentration of lysine at room temperature and $\mathrm{pH}=10.0$.

Figure 5. Top: ${ }^{1} \mathrm{H} \rightarrow{ }^{13} \mathrm{C} \mathrm{CP}-\mathrm{MAS} \mathrm{NMR}$ spectra of (a) bulk lysine, (b) ${ }^{13} \mathrm{C},{ }^{15} \mathrm{~N}-\mathrm{Ly}$ sine $\cdot 2 \mathrm{HCl}$, (c) ${ }^{13} \mathrm{C},{ }^{15} \mathrm{~N}-\mathrm{Lysine} \cdot 2 \mathrm{NaCl}$, (d) $\mathrm{Lys} / \mathrm{SiO}{ }^{-}$ $0.01 \mathrm{M}$ and $(\mathrm{e}){ }^{13} \mathrm{C},{ }^{15} \mathrm{~N}$-Lysine/ $\mathrm{SiO}_{2}(0.01 \mathrm{M})$. The spectra were collected with a MAS speed of $10 \mathrm{kHz}$, a relaxation delay time of $3 \mathrm{~s}$ and a contact time of $1.0 \mathrm{~ms}$. Bottom: ${ }^{1} \mathrm{H} \rightarrow{ }^{15} \mathrm{~N}$ CP-MAS NMR spectra of (a) bulk lysine, (b) ${ }^{13} \mathrm{C},{ }^{15} \mathrm{~N}-$ lysine $\cdot 2 \mathrm{HCl}$ and $(\mathrm{c}){ }^{13} \mathrm{C},{ }^{15} \mathrm{~N}-\mathrm{Ly}$ sine/SiO 2 $(0.01 \mathrm{M})$. The spectra were collected with a MAS speed of $10 \mathrm{kHz}$, a relaxation delay time of $3 \mathrm{~s}$ and a contact time of $1.0 \mathrm{~ms}$. Both ${ }^{1} \mathrm{H} \rightarrow{ }^{13} \mathrm{C}$ and ${ }^{1} \mathrm{H} \rightarrow{ }^{15} \mathrm{~N}$ CP-MAS NMR experiments were carried out at a ${ }^{1} \mathrm{H}$ Larmor frequency of $400 \mathrm{MHz}$ with a $4.0 \mathrm{~mm}$ triple resonance probe operating in triple resonance $\left({ }^{1} \mathrm{H} /{ }^{13} \mathrm{C} /{ }^{15} \mathrm{~N}\right)$ mode and a $3.2 \mathrm{~mm}$ triple resonance probe operating in triple resonance $\left({ }^{1} \mathrm{H} /{ }^{13} \mathrm{C} /{ }^{15} \mathrm{~N}\right)$ mode, respectively.

Figure 6. ${ }^{1} \mathrm{H}$ NMR spectra of (a) natural abundance bulk lysine and (b) ${ }^{13} \mathrm{C},{ }^{15} \mathrm{~N}$-Lysine/ $\mathrm{SiO}_{2}$ at a MAS speed of $67 \mathrm{kHz}$. Spectra were collected at a ${ }^{1} \mathrm{H}$ Larmor frequency of $850 \mathrm{MHz}$.

Figure 7. ${ }^{1} \mathrm{H}-{ }^{13} \mathrm{C} 2 \mathrm{D}-\mathrm{HETCOR}$ NMR spectrum of ${ }^{13} \mathrm{C},{ }^{15} \mathrm{~N}$-Lysine/SiO $\mathrm{S}_{2}$ with different mixing times $(0.25 \mathrm{~ms}, 2.0 \mathrm{~ms})$. Experiments were done at a ${ }^{1} \mathrm{H}$ Larmor frequency of $800 \mathrm{MHz}$ with a $1.6 \mathrm{~mm}$ triple resonance probe operating in double resonance $\left({ }^{1} \mathrm{H} /{ }^{13} \mathrm{C}\right)$ mode and a MAS speed of $35 \mathrm{kHz}$.

Figure 8. ${ }^{1} \mathrm{H} \rightarrow{ }^{13} \mathrm{C} \mathrm{CP}-\mathrm{MAS} N \mathrm{NR}$ spectra of (a) $\mathrm{Lys} / \mathrm{SiO}_{2}-0.01 \mathrm{M}$ and (b) $\mathrm{Lys} / \mathrm{SiO}_{2}-0.10 \mathrm{M}$, (c) $\mathrm{Lys} / \mathrm{SiO}_{2}-0.10 \mathrm{M} / \mathrm{NaCl}$. The experiments were carried out at a ${ }^{1} \mathrm{H}$ Larmor frequency of $400 \mathrm{MHz}$ with a $4.0 \mathrm{~mm}$ triple resonance probe operating in triple resonance $\left({ }^{1} \mathrm{H} /{ }^{13} \mathrm{C} /{ }^{15} \mathrm{~N}\right)$ mode, a contact time of $1.0 \mathrm{~ms}$ and a MAS speed of $10 \mathrm{kHz}$.

Figure 9. Schematic of the favorable model for lysine adsorption on fume silica nanoparticles surfaces. 


\section{Table of Contents}

